\title{
Convenient synthetic access to fluorescent rhodacyclopentadienes via ligand exchange reactions ${ }^{\text {is }}$
}

\author{
Carolin Sieck, Daniel Sieh, Meike Sapotta, Martin Haehnel, Katharina Edkins, \\ Andreas Lorbach, Andreas Steffen, Todd B. Marder* \\ a Institut für Anorganische Chemie, Julius-Maximilians-Universität Würzburg, Am Hubland, 97074 Würzburg, Germany
}

\begin{abstract}
A B S T R A C T
We have previously reported the formation of fluorescent 2,5-bis(arylethynyl)rhodacyclopentadienes from the reaction of $\left[\mathrm{Rh}\left(\kappa^{2}-O, O-\mathrm{acac}\right)\left(\mathrm{PMe}_{3}\right)_{2}\right]$ (acac $=$ acetylacetonato) with $\alpha, \omega$-bis(arylbutadiynyl)alkanes. However, a second isomer series, namely phosphorescent rhodium biphenyl complexes, was also obtained from the same reaction mixture, which made purification of the 2,5-bis(arylethynyl)rhodacyclopentadienes challenging and led to low isolated yields. Herein, we describe a synthetic protocol to access the desired fluorescent rhodium complexes by reaction of $\left[\mathrm{Rh}\left(\kappa^{2}-O, O-\mathrm{acac}\right)\left(\mathrm{P}(p \text {-tolyl })_{3}\right)\right]$ with $\alpha, \omega$-bis(arylbutadiynyl)alkanes, which gives exclusively 2,5-bis(arylethynyl)rhodacyclopentadienes, and subsequent phosphine ligand exchange. The rhodacyclopentadienes bearing $\mathrm{P}\left(p\right.$-tolyl $\left.{ }_{3}\right)$ ligands have been investigated and compared to their $\mathrm{PMe}_{3}$ analogs with regard to their photophysical properties, showing that the aromatic phosphine ligands enhance non-radiative decay from the singlet excited state $S_{1}$, while no phosphorescence from $T_{1}$ is observed despite the presence of the heavy rhodium atom. One of the $\mathrm{P}\left(p\right.$-tolyl $\left.\mathrm{H}_{3}\right)$ ligands can also be exchanged for an $\mathrm{N}$-heterocyclic carbene (NHC), leading to unsymmetrically coordinated rhodacyclopentadienes.
\end{abstract}

\section{Introduction}

Transition metal complexes bearing 2,2'-bipyridine- (bpy) and 2-phenylpyridine-(ppy)-type chromophore ligands have successfully been employed in photocatalysis, light-emitting devices, and biological imaging as a result of detailed investigations of their structure-property relationships [1]. The prototypical compounds $\left[\mathrm{Ru}(\mathrm{bpy})_{3}\right]^{2+}$ and $\left[\operatorname{Ir}(\mathrm{ppy})_{3}\right]$, and derivatives thereof, have been most extensively studied to understand their excited-state behavior, and it soon became clear that the combination of heavy metals exhibiting exceptionally high intrinsic spin-orbit coupling (SOC) with a variety of different ligands allows facile tuning of the excited states $[2,3]$. As a consequence, the strong SOC of the metal atom facilitates intersystem-crossing (ISC), which quenches the fluorescence from the excited singlet state $\left(S_{1}\right)$. For example, ultrafast conversion of the $S_{1}$ state to the $T_{n}$ states on the timescale of vibrations (few femtoseconds) has been measured for $\left[\mathrm{M}(\mathrm{bpy})_{3}\right]^{2+}$

\footnotetext{
Dedicated to Professor John Gladysz on the occasion of his 65th birthday.

* Corresponding author

E-mail address: todd.marder@uni-wuerzburg.de (T.B. Marder).
}

( $\mathrm{M}=\mathrm{Fe}, \mathrm{Ru}$ ) [4,5]. In addition, the spin-forbidden nature of the radiative transition between $T_{1}$ and the ground state $\left(S_{0}\right)$ is partially removed by the SOC and, as a result, phosphorescence with lifetimes of a few $\mu$ s and quantum yields $\left(\Phi_{\mathrm{P}}\right)$ of up to unity can be observed [6-8].

In contrast to transition metal complexes of bpy and ppy, little is known about the photophysical properties of metallacyclopentadienes as $\mathrm{MC}_{4}$ analogs. Investigations have been focussed on the catalytic activity of $2,2^{\prime}$-biphenylene (bph) complexes and only a limited number of bph complexes of Ir, Pd and Pt were explored with regard to their photophysical properties, although they show promising results with phosphorescence quantum yields of up to $16 \%$ and lifetimes of $\tau=3-14 \mu$ s [9]. The lack of photophysical reports in the literature is presumably due to limited synthetic access to bph transition-metal complexes, which are usually obtained via insertion of a low valent and electron-rich metal fragment into a $\mathrm{C}-\mathrm{C}$ bond of biphenylene or via reaction of a 2,2 -dihaliated biphenyl with a metal dihalide [10,11]. In contrast, structurally related main group $\mathrm{EC}_{4}$ systems such as boroles [12], siloles [13], thiophenes [14] and phospholes [15] are well known and have attracted significant attention due to their electrontransporting and optical properties (linear and non-linear optical 
behaviour), motivating us to explore the potential of metallacyclopentadienes.

Synthetic access to $\mathrm{MC}_{4}$ ring systems is possible by reductive coupling of 1,3-butadiynes at a suitable transition-metal precursor complex [16]. From a photophysical perspective, the most interesting of the possible isomers are the 2,5-conjugated ring systems. However, most of these reactions do not occur with the desired regioselectivity, as found for cobalt, titanium [17] or ruthenium [18] complexes. In 2001, Marder and co-workers successfully developed a high-yield one-pot synthesis of luminescent 2,5-bis(arylethynyl) rhodacyclopentadienes by reductive coupling of 1,4-diarylbuta-1,3diynes [16]. Over the past years, a variety of ligands and 1,4-bis $(p-R-$ phenyl)-1,3-butadiynes ( $\mathrm{R}=\mathrm{H}, \mathrm{Me}, \mathrm{OMe}, \mathrm{SMe}, \mathrm{CO}_{2} \mathrm{Me}$, etc.) were used. Remarkably, reactions of $\left[\mathrm{RhR}\left(\mathrm{PMe}_{3}\right)_{4}\right]\left(\mathrm{R}=\mathrm{C} \equiv \mathrm{CSiMe}_{3}, \mathrm{Me}\right)$ with two equivalents of 1,4-diarylbuta-1,3-diynes and also reactions of $\left[\mathrm{Rh}\left(\mathrm{C} \equiv \mathrm{CSiMe}_{3}\right)\left(\mathrm{PMe}_{3}\right)_{4}\right]$ or $\left[\mathrm{Rh}\left(\kappa^{2}-S, S-\mathrm{S}_{2} \mathrm{CNEt}_{2}\right)\left(\mathrm{PMe}_{3}\right)_{2}\right]$ with different linked $\alpha, \omega$-bis(arylethynyl)alkanes (rigidification of the rhodacycle backbone) yields quantitatively, in all cases, only the 2,5-bis(arylethynyl)rhodacyclopentadiene isomer (Scheme 1) $[19,20]$.

Surprisingly, our rhodacyclopentadienes exhibit highly efficient fluorescence with quantum yields of up to $69 \%$, despite the presence of the heavy atom that would be expected to facilitate rapid ISC and thus to quench the fluorescence. In 2014, we carried out a detailed photophysical analysis of 2,5-bis(arylethynyl)rhodacyclopentadienes to provide a full picture of their excited state behavior in order to understand these unusual photophysical properties. The origin of the fluorescence lies in the pure intra-ligand (IL) nature of the excited states $S_{1}$ and $T_{1}$, irrespective of the presence of a heavy atom. The HOMO and the LUMO are nearly pure $\pi$ and $\pi^{*}$ ligand orbitals, respectively, and the HOMO is energetically well separated from the filled Rh d orbitals. This inhibits low-energy MLCT transitions, leading to a low triplet state density around $S_{1}$ and hampering the ISC process $[20,21]$. In combination with that, structural distortion toward a cumulenic geometry in the $T_{1}$ state leads to weak coupling of the different spin states and thus to "organic-like" photophysical behavior. To investigate in more detail the effect on the properties of the 2,5-bis(arylethynyl)rhodacyclopentadienes, another $\pi$-electron-donating group, namely acac (acetylacetonato), was introduced into the rhodium precursor. Interestingly, reaction of [ $\left.\mathrm{Rh}\left(\kappa^{2}-O, O-\mathrm{acac}\right)\left(\mathrm{PMe}_{3}\right)_{2}\right]$ [22] with linked bis(diynes) led not only to the formation of fluorescent 2,5bis(arylethynyl)rhodacyclopentadienes (A), but also to isomeric and phosphorescent rhodium biphenyl complexes (B) (Scheme 2) [23].

The fundamentally different photophysical properties of $\mathbf{B}$ in comparison of $\mathbf{A}$ arise from the energetic proximity of the filled frontier orbitals in $\mathbf{B}$, which are mixtures of ligand $\pi$ and metal $\mathrm{d}$ orbitals. As a result, a number of triplet excited states with some metal to ligand charge-transfer (MLCT) contribution can efficiently connect the $S_{1}$ state with the emitting $T_{1}$ state. As no fluorescence for isomer B is detected even at low temperature, it can be assumed that $S_{1} \rightarrow T_{n}$ ISC must be faster than both fluorescence and nonradiative decay from $S_{1}[23]$. This contrasts with the behavior of the isomeric rhodacyclopentadienes $(\mathbf{A})$ for which we have previously shown that the unusual ISC occurs on a timescale that is competitive with fluorescence, as mentioned above. Such longlived triplet excited states of the rhodium biphenyl complexes (B), on a timescale of tens to hundreds of microseconds, can be very useful for applications in color-tunable OLEDs, in which, at high

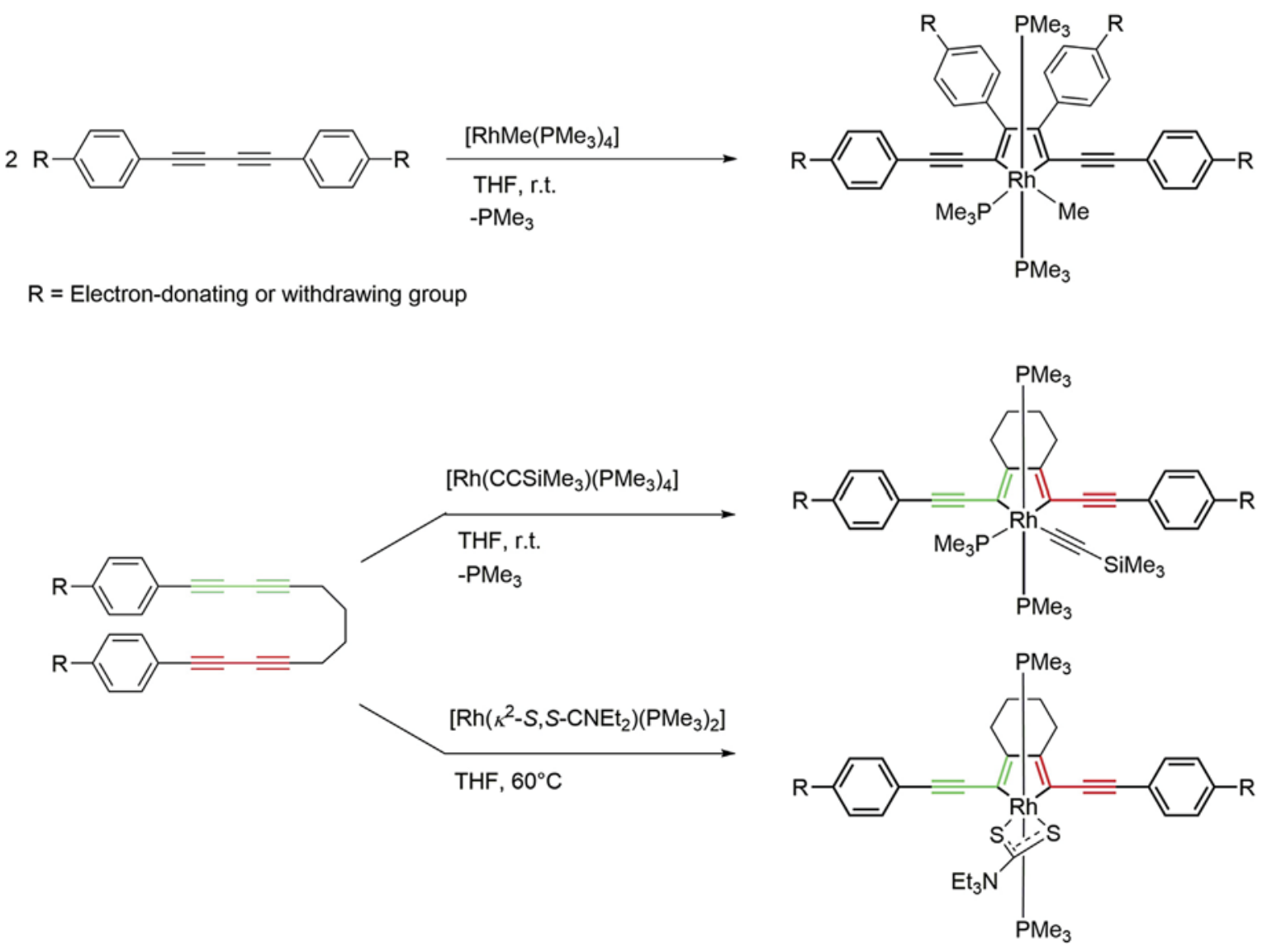

Scheme 1. Synthesis of 2,5-bis(arylethynyl)rhodacyclopentadienes [19,21]. 


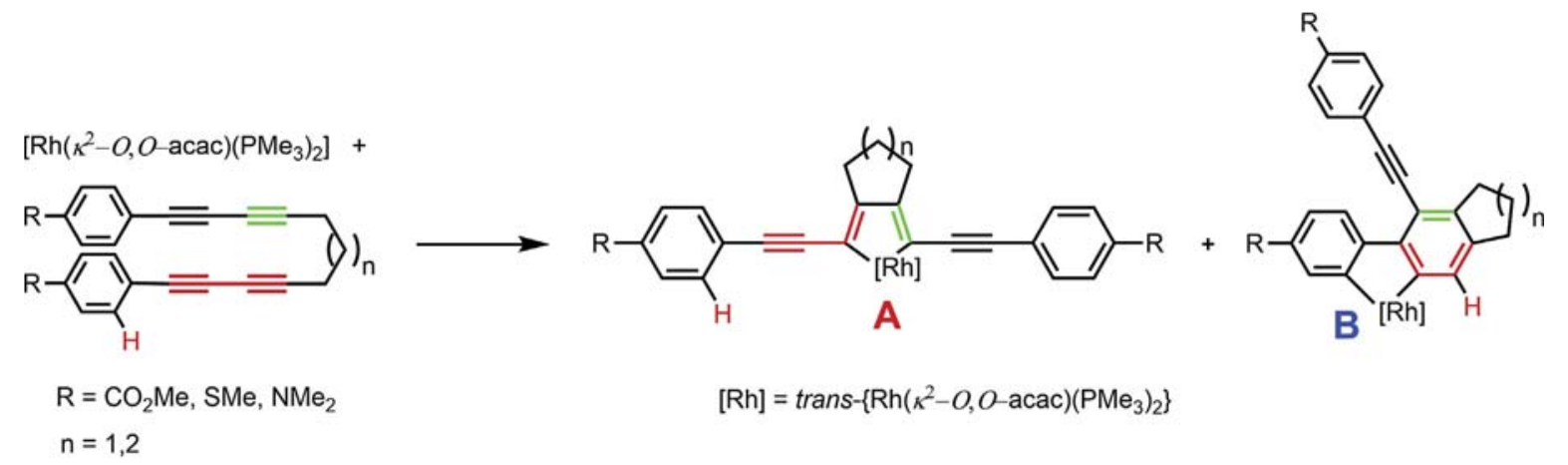

Scheme 2. Synthesis of two isomers: Rhodacyclopentadiene (A) and rhodium biphenyl complex (B) [23].

voltages, the emissive excited state of a low-energy emitter must have a long lifetime in order to become saturated by energy transfer from a short-lived high-energy luminophore. Also, long-lived excited states are of interest for photocatalysis, energy upconversion and non-linear optics, as has been shown for $\operatorname{Pd}(\mathrm{II})$ porphyrin and $\mathrm{Au}$ (III) 2,6-diphenylpyridine complexes [24].

As already mentioned above, metal biphenyl complexes of type B are difficult to prepare due to limited synthetic methods, and their photophysical properties are typically hence rather less well investigated then their $\left\{\mathrm{M}\left(\kappa^{2}-N, C-C_{3} N\right)\right\}$ or $\left\{\mathrm{M}\left(\kappa^{2}-N, N^{\prime}-C_{2} N_{2}\right)\right\}$ analogs (e.g. ppy or bpy complexes). We found that the product ratio of isomers $\mathbf{A}$ and $\mathbf{B}$ (Scheme 2) depends on the temperature, with isomer B being favored at higher temperatures. Different substituents at the aryl rings also lead to different isomer distributions. In addition, modification of the $\alpha, \omega$-bis-(arylbutadiynyl)alkane, i.e., changing the linker length from 4 to $3 \mathrm{CH}_{2}$ groups, dramatically favors formation of the rhodium biphenyl isomer $\mathbf{B}$ for entropic reasons, leading to an $\mathbf{A}: \mathbf{B}$ ratio of 1:20 at room temperature and $1: 25$ at higher temperatures, which makes it challenging to isolate isomer $\mathbf{A}$ in high yields [23]. These findings motivated us to develop a different approach that selectively produces isomer $\mathbf{A}$, and to investigate the influence of the ligand sphere around the rhodium center on the ISC processes by changing the phosphine ligands to more $\sigma$-donating $N$-heterocyclic carbene (NHCs) ligands.

\section{Results and discussion}

2.1. Synthesis, structural characterization and optical properties of 2,5-bis(arylethynyl)rhodacyclopenta-2,4-dienes

The reaction of $\left[\mathrm{Rh}\left(\kappa^{2}-O, O-\mathrm{acac}\right)\left(\mathrm{P}(p \text {-tolyl })_{3}\right)_{2}\right](\mathbf{1})$, which was characterized by single-crystal X-ray diffraction (see S7), with either $\alpha, \omega$-bis(arylbutadiynyl)alkane $\mathbf{2}$ or $\mathbf{3}$ in a 1:1 ratio leads to nearly full conversion to 2,5-bis(arylethynyl)rhodacyclopentadienes 4 and 5 (Scheme 3), respectively. These were purified by column chromatography and several recrystallizations to give samples of very high purity for photophysical investigations, resulting in moderate isolated yields. Rhodium complexes $\mathbf{4}$ and $\mathbf{5}$ were fully characterized by elemental analysis, mass spectrometry and multi-nuclear NMR spectroscopy.

Inspection of the NMR spectroscopic data revealed the formation of a $C_{2 v}$ symmetric complex on the NMR time scale as indicated by only one resonance for the acac $\mathrm{CH}_{3}$ protons and only one phosphine signal. The ${ }^{31} \mathrm{P}\left\{{ }^{1} \mathrm{H}\right\}$ NMR resonances of the complexes 4 and 5 are observed at 24.6 and 24.8 ppm, respectively, with rhodium phosphorus coupling constants of 114 (4) and $115 \mathrm{~Hz}(5)$, the $J_{\mathrm{Rh}-\mathrm{P}}$ values being in agreement with the data obtained for other rhodacyclopentadiene complexes bearing trimethylphosphine ligands [23].

Single-crystals suitable for X-ray diffraction analysis were obtained by vapor diffusion of hexane into THF solutions of $\mathbf{4}$ and $\mathbf{5}$, respectively, and the molecular structures are depicted in Fig. 1. The molecular geometries of $\mathbf{4}$ and $\mathbf{5}$ are very similar, the rhodium atom being in an octahedral coordination environment with transdisposed phosphine ligands. The Rh-P bond distances in $\mathbf{4}$ and $\mathbf{5}$ are in the range of $2.3464(8)-2.3637(8) \AA$ and are therefore slightly longer than in the corresponding $\mathrm{PMe}_{3}$ complexes (ca. $2.306 \AA$ ) [23], or 1 (2.0549(14), 2.0857(14) Å; see Table S1), indicating weaker metal phosphine bonding in $\mathbf{4}$ and $\mathbf{5}$. As the $\mathrm{C}-\mathrm{Rh}-\mathrm{C}$ angle within the rhodacyclopentadiene ring is only $81^{\circ}$ in both complexes 4 and 5, the other angles within the ring are larger $\left(113-117^{\circ}\right)$ than the expected $108^{\circ}$ for a regular planar, five membered ring. However, the sum of angles in the rhodacycle is $540^{\circ}$ in both compounds. At $1.358(5)-1.368(4) \AA$, the $C=C$ double bonds are basically the same than typical cyclopenta-1,3-diene $\mathrm{C}\left(\mathrm{sp}^{2}\right)=\mathrm{C}\left(\mathrm{sp}^{2}\right)$ bonds, and the single bond length of 1.431(4),
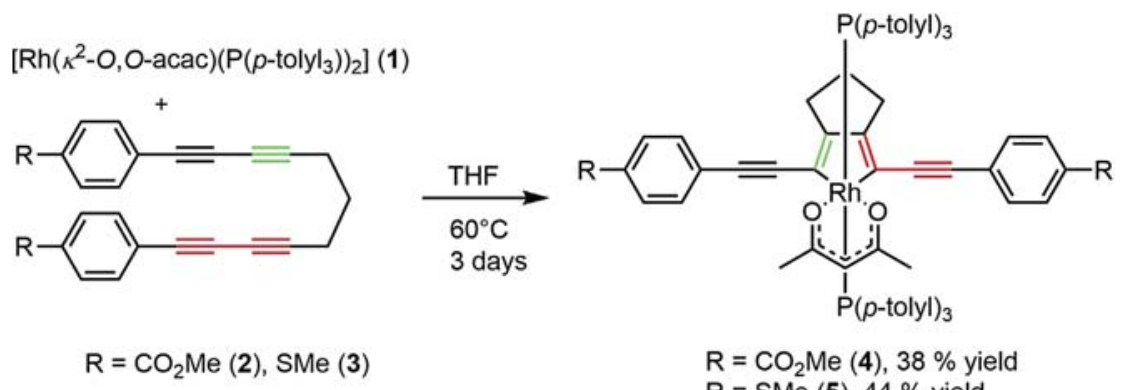

$\mathrm{R}=\mathrm{CO}_{2} \mathrm{Me}(4), 38 \%$ yield
$\mathrm{R}=\mathrm{SMe}(5), 44 \%$ yield

Scheme 3. Synthesis of 2,5-bis(arylethynyl)rhodacyclopentadienes $\mathbf{4}$ and $\mathbf{5}$ via reaction of $\left[\mathrm{Rh}\left(\kappa^{2}-0,0-\mathrm{acac}\right)\left(\mathrm{P}(p \text {-tolyl }]_{3}\right)_{2}\right](\mathbf{1})$ with $\alpha, \omega$-bis(arylbutadiynyl)alkanes $\mathbf{2}$ and $\mathbf{3}$, respectively. 


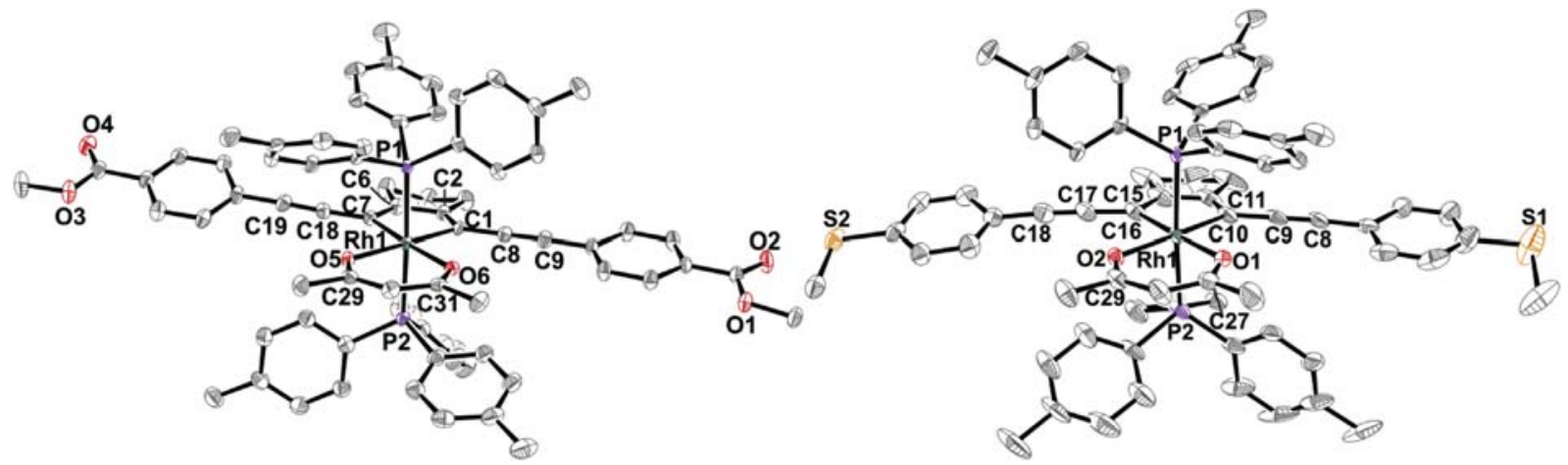

Fig. 1. Molecular structures of 2,5-bis(arylethynyl)rhodacyclopentadienes $\mathbf{4}$ (left) and $\mathbf{5}$ (right) in the solid state determined by single-crystal X-ray diffraction with the anisotropic displacement ellipsoids shown at the $50 \%$ probability level; $\mathrm{H}$ atoms are omitted for clarity.

1.433(5) $\AA$ are also typical for endocyclic $\mathrm{C}\left(\mathrm{sp}^{2}\right)-\mathrm{C}\left(\mathrm{sp}^{2}\right)$ bonds [25]. In both complexes, one of the aryl rings at the alkyne groups is nearly coplanar with the five membered metallacycle $\left(9^{\circ}\right)$, while the other one is slightly more twisted $\left(23.47(13)^{\circ}\right.$ in 4 and $16.02(17)^{\circ}$ in $\left.\mathbf{5}\right)$.

Being intrigued by the highly unusual fluorescence properties of previously reported 2,5-bis(arylethynyl)rhodacyclopentadienes containing $\mathrm{PMe}_{3}$ ligands, we also explored the photophysical properties of the tri( $p$-tolyl)phosphine complexes $\mathbf{4}$ and 5. Compounds $\mathbf{4}$ and $\mathbf{5}$ show a low-energy absorption band in the visible region of the electromagnetic spectrum with $\lambda_{\max }^{a b s}=563 \mathrm{~nm}$ and $\lambda_{\max }^{a b s}=525 \mathrm{~nm}$, respectively, and a broad emission with $\lambda_{\max }^{e m}=583 \mathrm{~nm}$ and $\lambda_{\max }^{e m}=550 \mathrm{~nm}$, respectively. The $\mathrm{CO}_{2} \mathrm{Me}-$ substituted compound $\mathbf{4}$ shows a bathochromic shift in the absorption and emission spectrum in comparison to its SMesubstituted congener $\mathbf{5}$, the influence of the acceptor substituent exceeding that of the donor. The effect of donors and acceptors can be explained by acceptors having a greater influence on the lowest unoccupied molecular orbital (LUMO) than on the highest unoccupied molecular orbital (HOMO), and donors showing an opposite effect, therefore both decreasing the HOMO-LUMO gap, as previously reported for related 2,5-bis(arylethynyl)thiophenes ${ }^{[14 g]}$ and 2,5-bis(arylethynyl)rhodacyclopentadienes [19,20].

The results from luminescence measurements suggest that the emission occurs from the excited singlet state $S_{1}$, as small Stokes shifts $609 \mathrm{~cm}^{-1}$ (4) and $866 \mathrm{~cm}^{-1}$ (5) (Fig. 2) are observed [23]. The rhodacyclopentadienes $\mathbf{4}$ and $\mathbf{5}$ exhibit very weak fluorescence with quantum yields $\Phi_{\mathrm{PL}}<0.01$, and very short emission lifetimes in toluene at room temperature. However, for compounds $\mathbf{4}$ and $\mathbf{5}$, no additional phosphorescence is observed, as previously reported for our highly fluorescent 2,5-bis(arylethynyl)rhodacyclopentadienes. Presumably, vibrational modes of the tri( $p$-tolyl)phosphine ligands lead to the higher rate constants for non-radiative decay and are thus responsible for the low quantum yields compared to their corresponding $\mathrm{PMe}_{3}$ complexes [23].

\subsection{Phosphine ligand exchange reactions of 4 and 5}

The weak rhodium tri(p-tolyl)phosphine bond in $\mathbf{4}$ and $\mathbf{5}$ compared to that on related $\mathrm{PMe}_{3}$ complexes allows for facile ligand exchange reactions. In the presence of an excess of $\mathrm{PMe}_{3} \mathrm{a}$ stepwise reaction can be observed, giving first the monosubstituted, mixed phosphine intermediates $\mathbf{6}$ and $\mathbf{7}$ and, subsequently, full conversion to the 2,5-bis(arylethynyl)rhodacyclopentadienes 8 and $\mathbf{9}$ bearing only trimethylphosphine ligands (Scheme 4).

Monitoring the reaction by ${ }^{31} \mathrm{P}\left\{{ }^{1} \mathrm{H}\right\}$ NMR spectroscopy at room

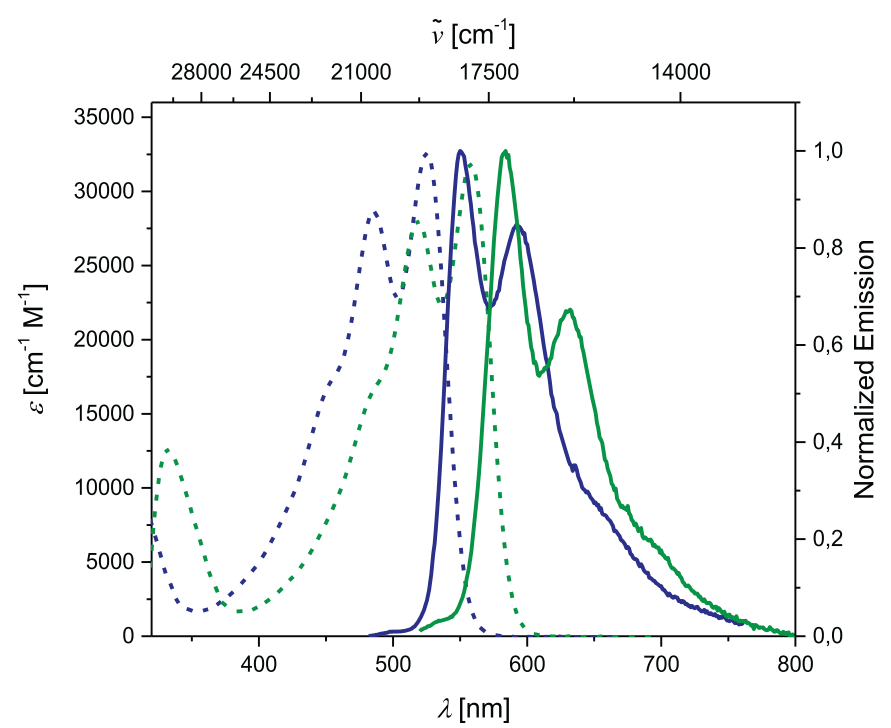

Fig. 2. Absorption (dashed lines) and emission spectra (solid lines, excited at the respective absorption maximum) of $\mathbf{4}$ (green) and $\mathbf{5}$ (blue) in degassed toluene at room temperature. (For interpretation of the references to colour in this figure legend, the reader is referred to the web version of this article.)

temperature, nearly full conversion of the starting material is observed with only traces of complex 4 being left after only $10 \mathrm{~min}$ (Fig. 3, top). The mono-substituted complex $\mathbf{6}$ is observed as the major product, giving rise to a doublet of doublets at $20.5 \mathrm{ppm}\left(\mathrm{J}_{\mathrm{Rh}}\right.$ $\left.\mathrm{P}=103 \mathrm{~Hz}, J_{\mathrm{P}-\mathrm{P}}=422 \mathrm{~Hz}\right)$ and at $4.7 \mathrm{ppm}\left(J_{\mathrm{Rh}-\mathrm{P}}=122 \mathrm{~Hz}, J_{\mathrm{P}-}\right.$ $\mathrm{P}=422 \mathrm{~Hz})$ for the $\mathrm{P}(p \text {-tolyl })_{3}$ and the $\mathrm{PMe}_{3}$ ligand, respectively, the trans disposition of the phosphines being clearly indicated of the ${ }^{2} J_{P-P}$ coupling constant. The final product 8 , with both tri( $p$-tolyl) phosphine ligands being exchanged [23], is already being formed to a small extent as evidenced by the doublet at $-1.0 \mathrm{ppm}\left(J_{\mathrm{Rh}}\right.$ $\mathrm{P}=113 \mathrm{~Hz}$ ). Upon warming the NMR sample to $60^{\circ} \mathrm{C}$, the signals for the starting compound $\mathbf{4}$ and the intermediate complex $\mathbf{6}$ disappear, and full conversion to the 2,5-bis(arylethynyl)rhodacyclopentadiene 7 as well as free tri(p-tolyl)phosphine occurs (Fig. 3, bottom). Very similar kinetic behavior is found for the conversion of 5 to 9.

Bearing in mind that the fast ligand exchange reaction is a result of the weaker rhodium-phosphine bond in $\mathbf{4}$ and $\mathbf{5}$ due to the lesser $\sigma$-donation of tri( $p$-tolyl)phosphine compared to trimethylphosphine [26], we also studied the reaction of the $\mathrm{P}(p$-tolyl 3$)$-based rhodium complex 5 with NHCs as even stronger $\sigma$-donors [27]. Addition of an excess of either 1,3-di(methyl)imidazol-2-ylidene 


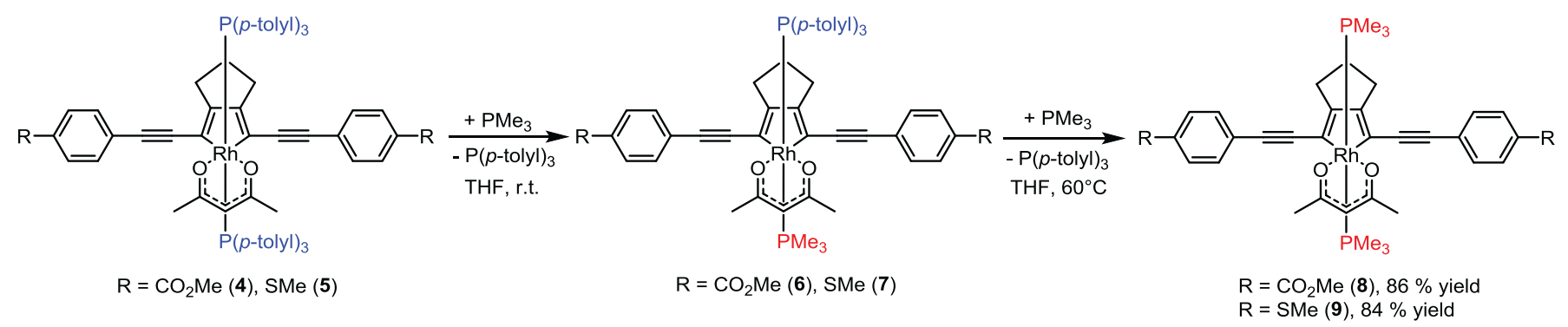

Scheme 4. Synthesis of 2,5-bis(arylethynyl)rhodacyclopentadienes 8 and $\mathbf{9}$ by stepwise ligand exchange.

$\left(\mathrm{Me}_{2} \operatorname{Im}, \mathbf{1 0}\right)$ or $1,3-\mathrm{di}\left(n\right.$-propyl)imidazol-2-ylidene $\left({ }^{n} \operatorname{Pr}_{2} \mathrm{Im}, \mathbf{1 1}\right)$ to a solution of $\mathbf{5}$ in toluene at room temperature led to the release of one equivalent of $\mathrm{P}\left(p\right.$-tolyl $\left.\mathrm{l}_{3}\right)$ and to the quantitative formation of the mono-substituted NHC rhodium complexes 12 and $\mathbf{1 3}$ respectively (Scheme 5 ). However, due to very similar solubility properties of the released phosphine ligand and the rhodium compounds, the products could only be isolated in ca. $6 \%$ yield. Interestingly, no conversion was observed in the case of bulkier $i \mathrm{Pr}_{2} \operatorname{Im}$.

For both complexes 12 and $\mathbf{1 3}$ a doublet is detected in the ${ }^{31} \mathrm{P}$ $\left\{{ }^{1} \mathrm{H}\right\}$ NMR spectrum at 21.7 and $21.8 \mathrm{ppm}$, respectively. The ${ }^{103} \mathrm{Rh}^{31} \mathrm{P}$ coupling constant of $101 \mathrm{~Hz}$ for both compounds is decreased by $15 \mathrm{~Hz}$ compared to that of the starting material $\mathbf{4}\left(J_{\mathrm{Rh}}\right.$ $\mathrm{P}=116 \mathrm{~Hz}$ ), which can be attributed to a weakening of the Rh-P bond [28], fully consistent with the enhanced trans influence of the stronger $\sigma$-donating NHC ligand in a trans-position to the phosphine. The ${ }^{13} \mathrm{C}\left\{{ }^{1} \mathrm{H}\right\}$ NMR spectra of both complexes 12 and 13 display a doublet of a doublet at $\delta=174 \mathrm{ppm}$ with coupling constants of $J_{\mathrm{P}-\mathrm{C}}=146 \mathrm{~Hz}$ and $J_{\mathrm{Rh}-\mathrm{C}}=48 \mathrm{~Hz}$, which we assign to the carbene carbon atoms bound to the rhodium metal center. Similar rhodium- $\mathrm{C}(\mathrm{NHC})$ coupling constants in the range of $40-60 \mathrm{~Hz}$ have been reported [29-31], and ${ }^{2} \mathrm{~J}$ phosphorus-carbene-carbon atom couplings above $100 \mathrm{~Hz}$ are commonly observed if the phosphine ligand is trans to the NHC ligand [32]. Respective cis P-C couplings, on the other hand, are often not larger than $20 \mathrm{~Hz}$ [32].

Single-crystals suitable for X-ray diffraction were obtained for complex 12. The molecular structure is shown in Fig. 4, with selected bond distances and angles being tabulated in Table S1. The molecular structure of $\mathbf{1 2}$ in the solid state (Fig. 4) confirms the conclusion from the NMR spectroscopic data that only one phosphine ligand was exchanged for a NHC ligand and that the phosphine and carbene ligands are mutually trans. The distance of the rhodium metal center to the carbene carbon atom (Rh1-C26) of $2.0889(17) \AA$ is in the typical range for octahedral rhodium(III) NHC complexes, but longer than reported for rhodium(I) complexes [33]. The Rh1-P1 distance of 2.3406(5) $\AA$ is almost identical to the Rh1phosphine distances of complex $\mathbf{5}$ (Avq. $=2.351 \AA$ ). Considering the strong $\sigma$-donating abilities of NHC ligands, a strong trans influence would be expected, so this observation is rather counterintuitive. However, phosphines and carbenes are both considered moderate trans influence ligands $[28,34]$ and indeed similar observations have been made by other groups. Nolan and co-workers for example observed only small elongations of the Rh-P bond length of about $0.015 \AA$ in rhodium complexes where a trans phosphine ligand is exchanged for a NHC ligand [32].

\section{Conclusion}

We have reported the reaction of $\mathrm{Rh}\left(\kappa^{2}-0,0\right.$-acac $\left.)\left(\mathrm{P}(p \text {-tolyl })_{3}\right)\right]$ with $\alpha, \omega$-bis(arylbuta-diynyl)alkanes, which leads to full conversion to 2,5-bis(arylethynyl)rhodacyclopentadienes. Subsequent stepwise, facile ligand exchange of $\mathrm{P}(p \text {-tolyl })_{3}$ by $\mathrm{PMe}_{3}$ provides convenient access to highly fluorescent 2,5-bis(arylethynyl)rhodacyclopentadienes, of which the optical properties have been reported previously [19-23]. In contrast to the very efficient fluorescence $S_{1} \rightarrow S_{0}$ observed in the $\mathrm{PMe}_{3}$-based complexes, their $\mathrm{P}(p \text {-tolyl })_{3}$ analogs show enhanced non-radiative decay rates, but still weak fluorescence in the visible region of the spectrum, being competitive with intersystem-crossing $\mathrm{S}_{1} \rightarrow \mathrm{T}_{\mathrm{n}}$. The ligand exchange reaction is also possible with one equivalent of more $\sigma$ donating NHC ligands, yielding unsymmetrically NHC/phosphinesubstituted rhodacyclopentadienes.

\section{Experimental}

General considerations: The compounds $\left[\mathrm{Rh}(\mu-\mathrm{Cl})(\mathrm{COE})_{2}\right]_{2}$ $(\mathrm{COE}=$ cyclooctene $)[35]\left[\mathrm{Rh}\left(\kappa^{2}-0,0-\mathrm{acac}\right)\left(\mathrm{PMe}_{3}\right)_{2}\right][22], 1,11-\mathrm{bis}(p-$ carbomethoxyphenyl)undeca-1,3,9,11-tetrayne (2) and 1,11-bis( $p$ methylthiophenyl)undeca-1,3,9,11-tetrayne (3) [23], 2,5(arylethynyl)rhodacyclopentadienes (8) and (9) [23], 1,3-di(methyl)imidazolin-2-ylidene ( $\left.\mathrm{Me}_{2} \mathrm{Im}\right)$ (10) [36], and 2,6-di( $n$-propyl) imidazolin-2-ylidene $\left({ }^{n} \mathrm{Pr}_{2} \mathrm{Im}\right)(\mathbf{1 1})$ [36] were prepared according to the literature. All other starting materials were purchased from commercial sources and used without further purification. All solvents for synthetic reactions were HPLC grade, further treated to remove traces of water using an Innovative Technology Inc. PureSolv Solvent Purification System and deoxygenated using the freeze-pump-thaw method. All reactions and subsequent manipulations were performed under an argon atmosphere in an Innovative Technology Inc. glovebox or using standard Schlenk techniques. NMR spectra were recorded on Bruker Avance 300 or 500 spectrometers, using $C_{6} D_{6}$ as the solvent. ${ }^{13} \mathrm{C}$ NMR spectra were broad-band proton-decoupled $\left({ }^{13} \mathrm{C}\left\{{ }^{1} \mathrm{H}\right\}\right)$. Chemical shifts are listed in parts per million (ppm) and were determined relative to internal $\mathrm{C}_{6} \mathrm{D}_{5} \mathrm{H}\left({ }^{1} \mathrm{H}, \delta=7.16 ; \mathrm{C}_{6} \mathrm{D}_{6}\right)$, to natural-abundance carbon resonances $\mathrm{C}_{6} \mathrm{D}_{6}\left({ }^{13} \mathrm{C}, \delta=128.06 ; \mathrm{C}_{6} \mathrm{D}_{6}\right)$ or external $85 \% \mathrm{H}_{3} \mathrm{PO}_{4}\left({ }^{31} \mathrm{P}, \delta=0\right)$. Coupling constants are quoted in Hertz. Aromatic peaks in the ${ }^{1} \mathrm{H}$ NMR spectra quoted as $\mathrm{d}$ are approximated as doublets resulting from more complex spin systems. Mass spectra were recorded on a Bruker Daltonics autoflex II LRF mass spectrometer operating in the MALDI mode. Elemental analyses were performed by the microanalytical laboratory of the Institute of Inorganic Chemistry of the University of Würzburg with an Elementar vario micro cube.

[Rh $\left(\boldsymbol{\kappa}^{2}-\mathbf{0 , 0}\right.$-acac $)\left(\mathbf{P}\left(\boldsymbol{p} \text {-tolyl } \mathbf{l}_{3}\right)_{2}\right](\mathbf{1})$ : A suspension of acetylacetone $(0.20 \mathrm{~g}, 9 \mathrm{mmol})$ and $\mathrm{KOH}(0.50 \mathrm{~g}, 8.5 \mathrm{mmol})$ in degassed THF $(50 \mathrm{~mL})$ was added to a solution of $\left[\mathrm{Rh}(\mu-\mathrm{Cl})(\mathrm{COE})_{2}\right]_{2}(1.5 \mathrm{~g}$, $4.18 \mathrm{mmol})$ in degassed THF $(5 \mathrm{~mL})$ and the reaction mixture was stirred for $1.5 \mathrm{~h}$ at room temperature. The volatiles were removed in vacuo and the resulting residue was extracted with hexane $(25 \mathrm{~mL})$ to give, after evaporation of the solvent, $\left[\mathrm{Rh}\left(\kappa^{2}-0, O-\mathrm{acac}\right)(\mathrm{COE})_{2}\right]$ [35]. The extract was added to a solution of $\mathrm{P}(p \text {-tolyl })_{3}$ (2.52 g, $8.3 \mathrm{mmol})$ in degassed toluene $(20 \mathrm{ml})$. The reaction mixture was 

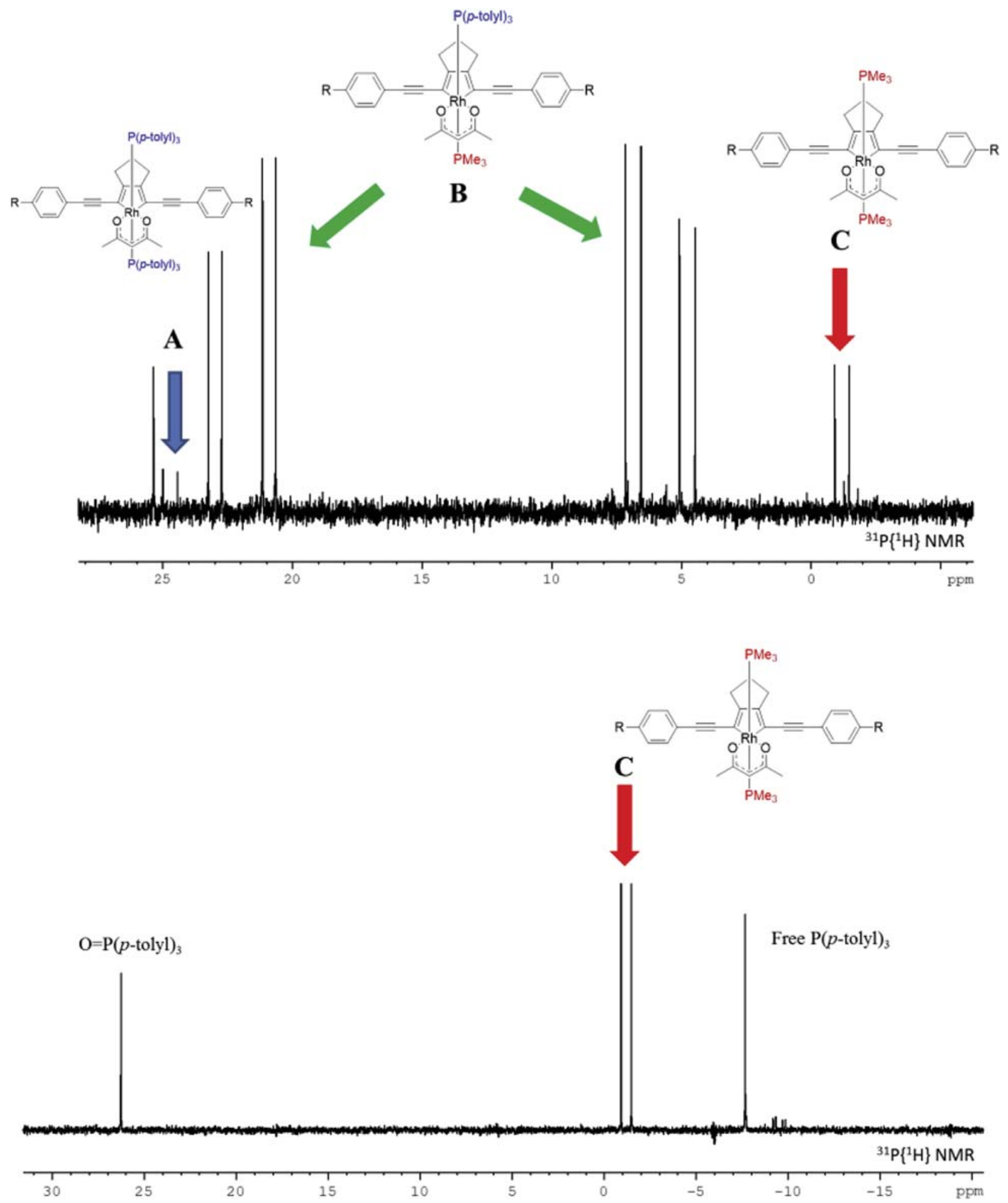

Fig. 3. In situ ${ }^{31} \mathrm{P}\left\{{ }^{1} \mathrm{H}\right\}$ NMR spectra $(202 \mathrm{MHz})$ of the reaction of 4 with an excess $\mathrm{PMe}_{3}$ in $\mathrm{C}_{6} \mathrm{D}_{6}$. Top: The mono-substituted complex $\mathbf{6}$ is the major product after 10 min at room temperature. Bottom: full conversion to 8 after heating at $60{ }^{\circ} \mathrm{C}$.

stirred and heated to reflux for $1 \mathrm{~h}$ and then the solvent was removed in vacuo. Compound $\mathbf{1}$ was isolated as an orange solid. Yield: $0.81 \mathrm{~g} \mathrm{(96 \% )}{ }^{1} \mathrm{H}$ NMR (300 MHz, $\mathrm{C}_{6} \mathrm{D}_{6}$, r.t., ppm) $\delta: 7.86(\mathrm{~m}$, $\left.12 \mathrm{H}, \mathrm{CH}_{\text {arom }}\right), 6.80$ (d, J $\left.=7 \mathrm{~Hz}, 12 \mathrm{H}, \mathrm{CH}_{\text {arom }}\right), 5.38(\mathrm{~s}, 1 \mathrm{H}$, acac- $\mathrm{CH})$, $2.00(\mathrm{~s}, 18 \mathrm{H}, p$-tolyl-CH 3$), 1.58\left(\mathrm{~s}, 6 \mathrm{H}\right.$, acac- $\left.\mathrm{CH}_{3}\right) .{ }^{31} \mathrm{P}\left\{{ }^{1} \mathrm{H}\right\} \mathrm{NMR}$ (121 MHz, $\mathrm{C}_{6} \mathrm{D}_{6}$, r.t., ppm) $\delta: 54.8\left(\mathrm{~d}, J_{\mathrm{Rh}-\mathrm{P}}=195 \mathrm{~Hz}, 2 \mathrm{P}\right)$. Elem. Anal.
Calcd. (\%) for $\mathrm{C}_{47} \mathrm{H}_{49} \mathrm{P}_{2} \mathrm{O}_{2} \mathrm{Rh}$ : C, 69.63; $\mathrm{H}, 6.09$. Found: C, 69.77; $\mathrm{H}$, 6.50. $\mathrm{MS}\left(\mathrm{ES}^{+}\right) \mathrm{m} / z=810\left[\mathrm{M}^{+}\right]$.

2,5-Bis(arylethynyl)rhodacyclopentadiene $(4): \quad\left[\mathrm{Rh}\left(\kappa^{2}-O, O-\right.\right.$ acac $\left.)\left(\mathrm{P}(p \text {-tolyl })_{2}\right)_{2}\right](\mathbf{1})(0.30 \mathrm{~g}, 0.37 \mathrm{mmol})$ and 1,11-bis $(p$-carbomethoxyphenyl)undeca-1,3,8,10-tetrayne (2) $(0.19 \mathrm{~g}, 0.37 \mathrm{mmol})$ were suspended in THF $(10 \mathrm{~mL})$ and the reaction mixture was 


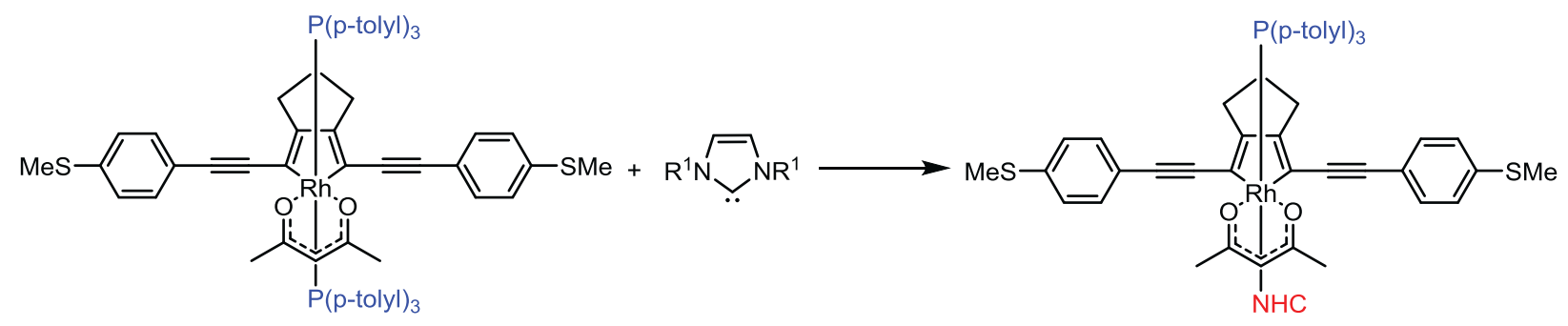

5

$\mathrm{R}^{1}=\mathrm{Me}(\mathbf{1 0}),{ }^{n} \operatorname{Pr}(11)$

12: $\mathrm{NHC}=\mathrm{Me}_{2} \mathrm{Im}, 5 \%$ yield 13: $\mathrm{NHC}={ }^{n} \mathrm{Pr}_{2} \mathrm{Im}, 6 \%$ yield

Scheme 5. Treatment of rhodacyclopentadiene $\mathbf{5}$ with an excess of NHC giving the mono-substituted complexes 12 and 13.

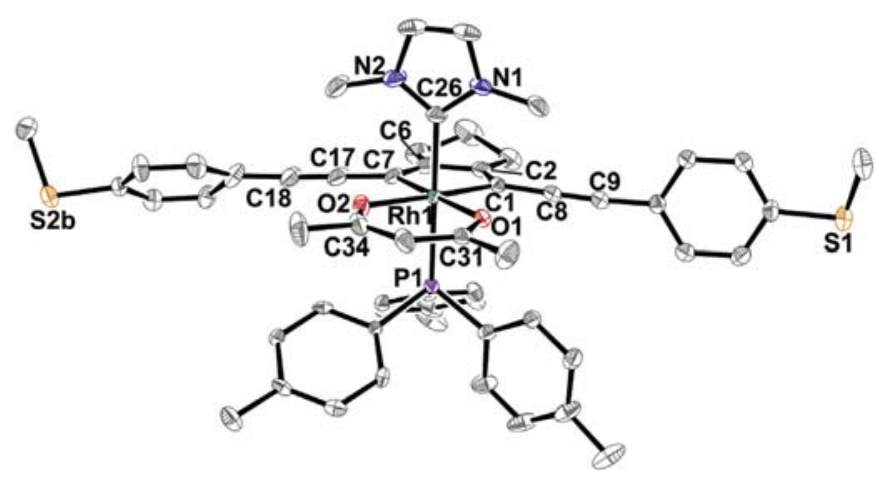

Fig. 4. Molecular structure of mono-substituted complex 12 in the solid state determined by single-crystal X-ray diffraction with the anisotropic displacement ellipsoids shown at the $50 \%$ probability level; $\mathrm{H}$ atoms are omitted for clarity. Selected bond distances ( $)$ : Rh1-C26 2.0889(17), Rh1-P1 2.3406(5).

stirred at $60{ }^{\circ} \mathrm{C}$ and monitored by ${ }^{31} \mathrm{P}\left\{{ }^{1} \mathrm{H}\right\}$ NMR spectroscopy. Once the reaction was complete, the volatiles were removed in vacuo. The product was purified via column chromatography $\left(\mathrm{Al}_{2} \mathrm{O}_{3}\right)$ eluting with hexane/THF (2:1), recrystallized and washed with hot hexane to give pure 4 as a red solid. Yield: $0.3 \mathrm{~g}(38 \%) .{ }^{1} \mathrm{H}$ NMR (300 MHz, $\mathrm{C}_{6} \mathrm{D}_{6}$, r.t., ppm) $\delta: 8.28\left(\mathrm{~d}, J=8 \mathrm{~Hz}, 4 \mathrm{H}, \mathrm{CH}_{\text {arom. }}\right), 8.00$ (m, $12 \mathrm{H}, p$-tolyl- $\mathrm{CH}_{\text {arom }}$ ), 7.90 (d, $\left.J=8 \mathrm{~Hz}, 4 \mathrm{H}, \mathrm{CH}_{\text {arom. }}\right), 6.93$ (d, $J=8 \mathrm{~Hz}, 12 \mathrm{H}, p$-tolyl-CHarom $), 4.65(\mathrm{~s}, 1 \mathrm{H}$, acac-CH $), 3.52(\mathrm{~s}, 6 \mathrm{H}$, $\left.\mathrm{CO}_{2} \mathrm{Me}-\mathrm{CH}_{3}\right), 2.06\left(\mathrm{~m}, 4 \mathrm{H}, \mathrm{CH}_{2}\right), 1.96\left(\mathrm{~s}, 18 \mathrm{H}, p\right.$-tolyl- $\left.\mathrm{CH}_{3}\right), 1.63(\mathrm{~m}$, $\left.2 \mathrm{H}, \mathrm{CH}_{2}\right), 1.55\left(\mathrm{~s}, 6 \mathrm{H}\right.$, acac- $\left.\mathrm{CH}_{3}\right) .{ }^{31} \mathrm{P}\left\{{ }^{1} \mathrm{H}\right\}$ NMR $\left(121 \mathrm{MHz}, \mathrm{C}_{6} \mathrm{D}_{6}\right.$, r.t., ppm) $\delta: 24.6\left(\mathrm{~d}, J_{\mathrm{Rh}-\mathrm{P}}=114 \mathrm{~Hz}, 2 \mathrm{P}\right) .{ }^{13} \mathrm{C}\left\{{ }^{1} \mathrm{H}\right\}$ NMR $(125.75 \mathrm{MHz}$, $\mathrm{C}_{6} \mathrm{D}_{6}$, r.t., ppm) $\delta: 185.8(\mathrm{~s}), 173.1(\mathrm{t}, J=3 \mathrm{~Hz}), 166.6(\mathrm{~s}), 139.4$ (d, $J=5 \mathrm{~Hz}), 135.8(\mathrm{t}, J=5 \mathrm{~Hz}), 132.4(\mathrm{~s}), 130.9(\mathrm{~s}), 130.1(\mathrm{~s}), 129.7(\mathrm{t}$, $J=23 \mathrm{~Hz}), 109.6(\mathrm{~d}, J=1 \mathrm{~Hz}), 102.2(\mathrm{~s}), 99.5(\mathrm{~s}), 51.5(\mathrm{~s}), 30.5(\mathrm{~s}), 30.1$ (s), 28.1 (s), 27.9 (s), 21.2 (s). Elem. Anal. Calcd. (\%) for $\mathrm{C}_{74} \mathrm{H}_{69} \mathrm{O}_{6} \mathrm{P}_{2} \mathrm{Rh}: \mathrm{C}, 72.90 ; \mathrm{H}, 5.70$. Found: $\mathrm{C}, 72.79 ; \mathrm{H}, 5.60$. MS (MALDI-TOF) $m / z$ : 1119 [ $\mathrm{M}^{+}$-acac], $914\left[\mathrm{M}^{+}-\mathrm{P}(p \text {-tolyl })_{3}\right]$.

2,5-Bis(arylethynyl)rhodacyclopentadiene $(5):\left[\operatorname{Rh}\left(\kappa^{2}-O, O-\right.\right.$ acac $)\left(\mathrm{P}\left(p \text {-tolyl }{ }_{3}\right)_{2}\right](\mathbf{1})(0.20 \mathrm{~g}, 0.41 \mathrm{mmol})$ and 1,11-bis $(p$-thioanisyl $)$ undeca-1,3,8,10-tetrayne (3) $(0.33 \mathrm{~g}, 0.41 \mathrm{mmol})$ were suspended in THF $(10 \mathrm{~mL})$ and the reaction mixture was stirred at $60{ }^{\circ} \mathrm{C}$ and monitored by ${ }^{31} \mathrm{P}\left\{{ }^{1} \mathrm{H}\right\}$ NMR spectroscopy. Once the reaction was complete, the volatiles were removed in vacuo. The product was purified via column chromatography $\left(\mathrm{Al}_{2} \mathrm{O}_{3}\right)$ eluting with hexane/ THF (2:1), recrystallized and washed with hot hexane to give pure 5 as a red solid. Yield: $0.4 \mathrm{~g}(44 \%) .{ }^{1} \mathrm{H}$ NMR $\left(300 \mathrm{MHz}, \mathrm{C}_{6} \mathrm{D}_{6}\right.$, r.t., ppm) $\delta: 8.07\left(\mathrm{~m}, 12 \mathrm{H}, p\right.$-tolyl-CH $\left.\mathrm{CH}_{\text {arom }}\right), 7.85\left(\mathrm{~d}, J=8 \mathrm{~Hz}, 4 \mathrm{H}, \mathrm{CH}_{\text {arom. }}\right.$ ), 7.21 (d, $\left.J=8 \mathrm{~Hz}, 4 \mathrm{H}, \mathrm{CH}_{\text {arom. }}\right), 6.96$ (d, $J=8 \mathrm{~Hz}, 12 \mathrm{H}, p$-tolyl-CH $\mathrm{CH}_{\text {arom. }}$ ), $4.65(\mathrm{~s}, 1 \mathrm{H}$, acac- $\mathrm{CH}), 2.07\left(\mathrm{~m}, 4 \mathrm{H}, \mathrm{CH}_{2}\right) 1.98\left(\mathrm{~s}, 6 \mathrm{H}, \mathrm{SMe}-\mathrm{CH}_{3}\right), 1.97$ (s, $18 \mathrm{H}, p$-tolyl-CH $), 1.61\left(\mathrm{~s}, 6 \mathrm{H}\right.$, acac- $\left.\mathrm{CH}_{3}\right) 1.58\left(\mathrm{~m}, 2 \mathrm{H}, \mathrm{CH}_{2}\right) .{ }^{31} \mathrm{P}$ $\left\{{ }^{1} \mathrm{H}\right\}$ NMR (121 MHz, $\mathrm{C}_{6} \mathrm{D}_{6}$, r.t., ppm) $\delta: 24.8\left(\mathrm{~d}, J_{\mathrm{Rh}-\mathrm{P}}=115 \mathrm{~Hz}, 2 \mathrm{P}\right)$.
${ }^{13} \mathrm{C}\left\{{ }^{1} \mathrm{H}\right\}$ NMR (125.75 MHz, $\mathrm{C}_{6} \mathrm{D}_{6}$, r.t., ppm) $\delta: 185.6(\mathrm{~s}), 171.2(\mathrm{t}$, $J=3 \mathrm{~Hz}), 139.1(\mathrm{~s}), 137.4(\mathrm{~s}), 136.0(\mathrm{t}, J=5 \mathrm{~Hz}), 135.9(\mathrm{~s}), 130.2(\mathrm{~s})$, $130.0(\mathrm{t}, J=23 \mathrm{~Hz}), 126.8(\mathrm{~s}), 124.6(\mathrm{~s}), 109.1(\mathrm{~d}, J=1 \mathrm{~Hz}), 99.3(\mathrm{~s})$, 98.7 (s), 31.9 (s), 30.1 (s), 28.2 (s), 27.9 (s), 21.2 (s), 15.3 (s). Elem. Anal. Calcd. (\%) for $\mathrm{C}_{72} \mathrm{H}_{69} \mathrm{O}_{6} \mathrm{P}_{2} \mathrm{RhS}_{2}$ : C, 72.35; H, 5.82; S, 5.37 . Found: C, 72.56; H, 5.96; S, 5.25. MS (MALDI-TOF) m/z: $1095\left[\mathrm{M}^{+}-\right.$ acac], $890\left[\mathrm{M}^{+}-\mathrm{P}(p \text {-tolyl })_{3}\right]$.

2,5-Bis(arylethynyl)rhodacyclopentadiene (8): Compound 4 $(0.20 \mathrm{~g}, 0.16 \mathrm{mmol})$ was dissolved in THF $(20 \mathrm{~mL})$. After the addition of $\mathrm{PMe}_{3}(0.03 \mathrm{~mL}, 0.32 \mathrm{mmol})$, the reaction mixture was stirred at $60{ }^{\circ} \mathrm{C}$. After one day, the volatiles were removed and $n$-hexane $(10 \mathrm{~mL})$ was added and then removed in vacuo in order to evaporate any remaining uncoordinated $\mathrm{PMe}_{3}$. For purification, gradientflash-chromatography was performed. The crude product was further purified by recrystallization from THF/hexane to yield 8 as a red solid (0.12 g, 86\%). ${ }^{1} \mathrm{H}$ NMR (300 MHz, $\mathrm{C}_{6} \mathrm{D}_{6}$, r.t., ppm) $\delta: 7.58$ (d, $\left.J=8 \mathrm{~Hz}, 4 \mathrm{H}, \mathrm{CH}_{\text {arom }}\right), 7.18$ (br s, $\left.4 \mathrm{H}, \mathrm{CH}_{\text {arom }}\right), 5.07(\mathrm{~s}, 1 \mathrm{H}, \mathrm{CH}), 2.71$ $\left(\mathrm{m}, 4 \mathrm{H}, \mathrm{CH}_{2}\right), 2.27\left(\mathrm{~s}, 6 \mathrm{H}, \mathrm{CH}_{3}\right), 2.10\left(\mathrm{~m}, 2 \mathrm{H}, \mathrm{CH}_{2}\right), 1.76\left(\mathrm{~s}, 6 \mathrm{H}, \mathrm{CH}_{3}\right)$, 0.95 (vt, $\left.{ }^{2} J_{\mathrm{P}-\mathrm{H}}=3 \mathrm{~Hz}, 18 \mathrm{H}, \mathrm{PMe}_{3}\right) .{ }^{13} \mathrm{C}\left\{{ }^{1} \mathrm{H}\right\} \mathrm{NMR}\left(126 \mathrm{MHz}, \mathrm{C}_{6} \mathrm{D}_{6}\right.$, r.t., ppm) $\delta: 186.4,156.5,144.6,132.9,129.6,128.4,98.2,30.9,30.5,28.3$, $21.4,12.5\left(\mathrm{vt},{ }^{1} \mathrm{~J}_{\mathrm{C}-\mathrm{P}}=14 \mathrm{~Hz}\right)$. Due to the low intensity two carbon signals coupled to Rh and/or P were not observed. ${ }^{31} \mathrm{P}\left\{{ }^{1} \mathrm{H}\right\}$ NMR (121 MHz, $\mathrm{C}_{6} \mathrm{D}_{6}$, r.t., ppm) $\delta:-3.0$ (d, $\left.{ }^{1} J_{\mathrm{Rh}-\mathrm{P}}=113 \mathrm{~Hz}, 2 \mathrm{P}\right)$. Elem. Anal. Calcd. (\%) for $\mathrm{C}_{38} \mathrm{H}_{45} \mathrm{O}_{6} \mathrm{P}_{2} \mathrm{Rh}$ : C, 59.85; $\mathrm{H}, 5.95$. Found: C, 59.55; H, 5.97. MS (MALDI-TOF) m/z: $762\left[\mathrm{M}^{+}\right], 663$ [M - acac $]^{+}[23]$.

2,5-Bis(arylethynyl)rhodacyclopentadiene (9): Compound 5 $(0.2 \mathrm{~g}, 0.17 \mathrm{mmol})$ was dissolved in THF $(20 \mathrm{~mL})$. After the addition of $\mathrm{PMe}_{3}(0.04 \mathrm{~mL}, 0.34 \mathrm{mmol})$, the reaction mixture was stirred at $60{ }^{\circ} \mathrm{C}$. After one day, the volatiles were removed and $n$-hexane $(10 \mathrm{~mL})$ was added and removed in vacuo in order to evaporate any remaining uncoordinated $\mathrm{PMe}_{3}$. For purification, gradient-flashchromatography was performed. The crude product was further purified by recrystallization from THF/hexane to yield $\mathbf{9}$ as a red solid $(0.10 \mathrm{~g}, 84 \%) .{ }^{1} \mathrm{H}$ NMR (300 MHz, $\mathrm{C}_{6} \mathrm{D}_{6}$, r.t., ppm) $\delta: 7.60$ (d, $J=8 \mathrm{~Hz}, 4 \mathrm{H}, \mathrm{CH}_{\text {arom }}$ ), 7.05 (br s, $4 \mathrm{H}, \mathrm{CH}_{\text {arom }}$ ), 5.15 (s, $\left.1 \mathrm{H}, \mathrm{CH}\right), 2.74$ $\left(\mathrm{m}, 4 \mathrm{H}, \mathrm{CH}_{2}\right), 2.19\left(\mathrm{~m}, 2 \mathrm{H}, \mathrm{CH}_{2}\right), 1.96\left(\mathrm{~s}, 6 \mathrm{H}, \mathrm{CH}_{3}\right), 1.92\left(\mathrm{~s}, 6 \mathrm{H}, \mathrm{CH}_{3}\right)$, 1.03 (vt, $\left.{ }^{2} \mathrm{P}_{\mathrm{H}-\mathrm{H}}=3 \mathrm{~Hz}, 18 \mathrm{H}, \mathrm{PMe}_{3}\right) .{ }^{13} \mathrm{C}\left\{{ }^{1} \mathrm{H}\right\}$ NMR $\left(126 \mathrm{MHz}, \mathrm{C}_{6} \mathrm{D}_{6}\right.$, r.t., ppm) $\delta: 186.3,165.9,136.8,131.0,126.4,124.0,107.0,98.5,94.9,30.1$, $29.9,28.2,15.0,10.7\left(\mathrm{vt},{ }^{1} \mathrm{JC}_{\mathrm{C}} \mathrm{P}=14 \mathrm{~Hz}\right)$. Due to the low intensity two carbon signals coupled to Rh and/or P were not observed. ${ }^{31} \mathrm{P}\left\{{ }^{1} \mathrm{H}\right\}$ NMR (121 MHz, $\mathrm{C}_{6} \mathrm{D}_{6}$, r.t., ppm) $\delta:-1.14\left(\mathrm{~d},{ }^{1} J_{\mathrm{Rh}-\mathrm{P}}=114 \mathrm{~Hz}, 2 \mathrm{P}\right)$. Elem. Anal. Calcd. (\%) for $\mathrm{C}_{36} \mathrm{H}_{45} \mathrm{O}_{2} \mathrm{P}_{2} \mathrm{RhS}_{2}$ : C, 58.53; $\mathrm{H}, 6.14 ; \mathrm{S}, 8.68$. Found: C, 58.92; H, 6.19 S, 8.23. MS (MALDI-TOF) $m / z: 738\left[\mathrm{M}^{+}\right]$ [23].

2,5-Bis(arylethynyl)rhodacyclopentadiene (12): Rhodacyclopentadiene $\mathbf{5}(0.10 \mathrm{~g}, 0.08 \mathrm{mmol})$ was dissolved in dry toluene and 1,3-di(methyl)imidazol-2-ylidene (10) (0.02 g, $0.22 \mathrm{mmol}$ ) was added. The reaction mixture was stirred at room temperature and monitored by NMR spectroscopy. After 7 days, no starting material could be detected anymore. The volatiles were removed in vacuo 
and the solid residue was washed three times with hexane. The dark orange crude product was removed from insoluble byproducts by dissolving in toluene and purified by precipitation from toluene/hexane at low temperature. Yield: $4.2 \mathrm{mg}(5 \%) .{ }^{1} \mathrm{H}$ NMR (500 MHz, $\mathrm{C}_{6} \mathrm{D}_{6}$, r.t., ppm) $\delta: 8.02-7.98\left(\mathrm{~m}, 6 \mathrm{H}, \mathrm{CH}_{\text {arom}}\right)$, 7.61-7.59 ( $\left.\mathrm{m}, 4 \mathrm{H}, \mathrm{CH}_{\text {arom }}\right), 7.18-7.16\left(\mathrm{~m}, 4 \mathrm{H}, \mathrm{CH}_{\text {arom }}\right), 6.99-6.97(\mathrm{~m}$, $\left.6 \mathrm{H}, \mathrm{CH}_{\text {arom }}\right), 5.77$ and $5.76(2 \mathrm{~s}, 2 \mathrm{H}, \mathrm{NCHCHN}), 4.88(\mathrm{~s}, 1 \mathrm{H}, \mathrm{acac}-\mathrm{H})$, $4.11\left(\mathrm{~s}, 6 \mathrm{H}, \mathrm{NCH}_{3}\right), 2.68-2.62\left(\mathrm{~m}, 2 \mathrm{H}, \mathrm{CH}_{2}\right), 2.38-2.30\left(\mathrm{~m}, 2 \mathrm{H}, \mathrm{CH}_{2}\right)$, 2.00 (s, 9H, tol- $\left.\mathrm{CH}_{3}\right), 1.99$ (s, 6H, $\left.\mathrm{SCH}_{3}\right), 1.95-1.86\left(\mathrm{~m}, 2 \mathrm{H}, \mathrm{CH}_{2}\right) 1.84$ (s, $6 \mathrm{H}$, acac $\left.-\mathrm{CH}_{3}\right) .{ }^{13} \mathrm{C}\left\{{ }^{1} \mathrm{H}\right\}$ NMR $\left(125 \mathrm{MHz}, \mathrm{C}_{6} \mathrm{D}_{6}\right.$, r.t., ppm) $\delta: 185.4$ $(\mathrm{s}), 174.0\left(\mathrm{dd}, J_{\mathrm{Rh}-\mathrm{C}}=144 \mathrm{~Hz}, J_{\mathrm{P}-\mathrm{C}}=46 \mathrm{~Hz}\right), 170.5(\mathrm{~s}), 138.8(\mathrm{~d}$, $J=2 \mathrm{~Hz}), 136.8(\mathrm{~s}), 135.7(\mathrm{~d}, J=10 \mathrm{~Hz}), 131.2(\mathrm{~s}), 130.8(\mathrm{dd}, J=34 \mathrm{~Hz}$, $J=12 \mathrm{~Hz}), 130.2(\mathrm{~d}, J=40 \mathrm{~Hz}), 126.9(\mathrm{~s}), 124.9(\mathrm{~s}), 121.9(\mathrm{~s}), 107.5(\mathrm{~d}$, $J=1 \mathrm{~Hz}), 100.5(\mathrm{~d}, J=1 \mathrm{~Hz}), 98.5(\mathrm{~s}), 39.0(\mathrm{~s}) 30.2(\mathrm{~s}), 28.6(\mathrm{~s}), 28.6$ (s), 21.2 (s), 15.5 (s). ${ }^{31} \mathrm{P}\left\{{ }^{1} \mathrm{H}\right\}$ NMR (202 MHz, $\mathrm{C}_{6} \mathrm{D}_{6}$, r.t., ppm) $\delta: 21.7$ $\left(\mathrm{d}, J_{\mathrm{Rh}-\mathrm{P}}=101 \mathrm{~Hz}\right.$ ). Elem. Anal. Calcd. (\%) $\mathrm{C}_{56} \mathrm{H}_{56} \mathrm{~N}_{2} \mathrm{O}_{2} \mathrm{PRhS}_{2}$ : C, 68.14; H, 5.72; N, 2.84. Found: C, 68.26; H, 6.09; N, 3.18.

2,5-Bis(arylethynyl)rhodacyclopentadiene (13): Rhodacyclopentadiene $\mathbf{5}(0.10 \mathrm{~g}, 0.08 \mathrm{mmol})$ was dissolved in dry toluene. After the addition of 1,3-di(n-propyl)imidazol-2-ylidene (11) (0.05 g, $0.34 \mathrm{mmol}$ ), the reaction mixture was stirred at room temperature and monitored by NMR spectroscopy. After 7 days, no starting material could be detected. The volatiles were removed in vacuo and the solid residue was washed three times with hexane. The red crude product was removed from insoluble by-products by dissolving in toluene and further purified by precipitation from toluene/hexane at low temperature. Yield: $4.9 \mathrm{mg}(6 \%) .{ }^{1} \mathrm{H}$ NMR (500 MHz, $\mathrm{C}_{6} \mathrm{D}_{6}$, r.t., ppm) $\delta: 7.98-7.95\left(\mathrm{~m}, 6 \mathrm{H}, \mathrm{CH}_{\text {arom }}\right), 7.58-7.56$ $\left(\mathrm{m}, 4 \mathrm{H}, \mathrm{CH}_{\text {arom }}\right), 7.17-7.14\left(\mathrm{~m}, 4 \mathrm{H}, \mathrm{CH}_{\text {arom }}\right), 6.98-6.96(\mathrm{~m}, 6 \mathrm{H}$, $\left.\mathrm{CH}_{\text {arom }}\right), 6.22(2 \mathrm{~s}, 2 \mathrm{H}, \mathrm{NCHCHN}), 4.91(\mathrm{~s}, 1 \mathrm{H}, \mathrm{acac}-\mathrm{H}), 4.73(\mathrm{~s}, 4 \mathrm{H}$, $\left.\mathrm{NCH}_{2}\right), 2.62-2.56\left(\mathrm{~m}, 2 \mathrm{H}, \mathrm{CH}_{2}\right), 2.37-2.30\left(\mathrm{~m}, 2 \mathrm{H}, \mathrm{CH}_{2}\right), 2.00(\mathrm{~s}, 9 \mathrm{H}$, tol- $\left.\mathrm{CH}_{3}\right), 2.00\left(\mathrm{~s}, 6 \mathrm{H}, \mathrm{SCH}_{3}\right), 1.96-1.88\left(\mathrm{~m}, 2 \mathrm{H}, \mathrm{CH}_{2}\right), 1.86(\mathrm{~s}, 6 \mathrm{H}$, acac$\left.\mathrm{CH}_{3}\right), 1.64\left(\mathrm{~m}, 4 \mathrm{H}, \mathrm{NCH}_{2} \mathrm{CH}_{2} \mathrm{CH}_{3}\right), 1.02\left(\mathrm{t}, 3 \mathrm{H}, J=7 \mathrm{~Hz}, \mathrm{NCH}_{2} \mathrm{CH}_{2} \mathrm{CH}_{3}\right)$. ${ }^{13} \mathrm{C}\left\{{ }^{1} \mathrm{H}\right\}$ NMR (125 MHz, $\mathrm{C}_{6} \mathrm{D}_{6}$, r.t., ppm) $\delta: 185.4$ (s), 174.1 (dd, $\left.J_{\mathrm{Rh}-\mathrm{C}}=146 \mathrm{~Hz}, J_{\mathrm{P}-\mathrm{C}}=48 \mathrm{~Hz}\right), 170.5(\mathrm{~s}), 138.7(\mathrm{~d}, J=2 \mathrm{~Hz}), 136.7(\mathrm{~s})$, 135.7 (d, $J=10 \mathrm{~Hz}), 131.3$ (s), 130.8 (dd, $J=34 \mathrm{~Hz}, J=13 \mathrm{~Hz}), 130.2$ (d, $J=40 \mathrm{~Hz}$ ), 126.7 (s), 124.4 (s), 120.1 (s), 120.0 (s), 106.8 (d, $J=1 \mathrm{~Hz}), 100.5$ (d, $J=1 \mathrm{~Hz}$ ), 98.5 (s), 51.7 (s), 30.2 (s), 28.7 (s), 28.5 (s), 25.7 (s), 21.2 (s), 15.5 (s), 11.8 (s) ppm. ${ }^{31} \mathrm{P}\left\{{ }^{1} \mathrm{H}\right\}$ NMR (202 MHz, $\mathrm{C}_{6} \mathrm{D}_{6}$, r.t., ppm) $\delta: 21.3\left(\mathrm{~d}, J_{\mathrm{Rh}-\mathrm{P}}=101 \mathrm{~Hz}\right)$. Elem. Anal. Calcd. (\%) $\mathrm{C}_{60} \mathrm{H}_{64} \mathrm{~N}_{2} \mathrm{O}_{2} \mathrm{PRhS}_{2}$ : C, 69.08; H, 6.18; N, 2.69. Found: C, 69.48; $\mathrm{H}$, 6.27; N, 2.92.

Crystallographic Details: The crystal data were collected on a Bruker X8-APEX II diffractometer with a CCD area detector and graphite monochromated $\mathrm{Mo}_{\mathrm{K} \alpha}$ radiation. The structures were solved using the intrinsic phasing method (ShelXT) or the olex2.solve structure solution program using Charge Flipping [37], refined with the ShelXL program [38] and expanded using Fourier techniques. All non-hydrogen atoms were refined anisotropically. Hydrogen atoms were included in structure factor calculations. All hydrogen atoms were assigned to idealized geometric positions. CCDC 1531337 for $\mathbf{1}, 1531334$ for $\mathbf{4}, 1531336$ for $\mathbf{5}$ and 1531335 for $\mathbf{1 2}$ contain the supplementary crystallographic data for this paper, which can be obtained free of charge from the Cambridge Crystallographic Data Centre via www.ccdc.cam.ac.uk/data_request/cif.

Crystal data for 1: $\mathrm{C}_{47} \mathrm{H}_{49} \mathrm{O}_{2} \mathrm{P}_{2} \mathrm{Rh}, M=810.71, a=13.9553(6) \AA$, $b=22.5210(10) \AA, c=14.2399(7) \AA, \alpha=90^{\circ}, \beta=114.662(2)^{\circ}$, $\gamma=90^{\circ}, V=4067.2(3) \AA^{3}, T=100(2) \mathrm{K}$, space group $P 2_{1} / c, Z=4$, 68252 reflections measured, 14603 independent reflections $\left(R_{\text {int }}=0.1070\right)$. The final $R_{1}$ values were $0.0419(I>2 \sigma(I))$ and 0.0781 (all data). The final $w R\left(F^{2}\right)$ values were $0.0823(I>2 \sigma(I))$ and 0.0938 (all data). The goodness of fit on $F^{2}$ was 1.003 .

Crystal data for 4: $\mathrm{C}_{74} \mathrm{H}_{69} \mathrm{O}_{6} \mathrm{P}_{2} \mathrm{Rh}, M=1219.14, a=11.9993(7) \AA$, $b=14.1960(8) \AA, c=19.5690(11) \AA, \alpha=103.2998(16)^{\circ}$, $\beta=104.3165(17)^{\circ}, \gamma=100.1056(17)^{\circ}, V=3046.4(3) \AA^{3}, T=100 \mathrm{~K}$, space group $P-1, Z=2,35722$ reflections measured, 12977 independent reflections $\left(R_{\text {int }}=0.0322\right.$ ). The final $R_{1}$ values were 0.0382 $(I>2 \sigma(I))$ and 0.0636 (all data). The final $\mathrm{w} R\left(F^{2}\right)$ values were 0.0994 $(I>2 \sigma(I))$ and 0.1276 (all data). The goodness of fit on $F^{2}$ was 1.087 .

Crystal data for 5: $\mathrm{C}_{72} \mathrm{H}_{69} \mathrm{O}_{2} \mathrm{P}_{2} \mathrm{RhS}_{2}, \quad M=1195.24$, $a=12.6624(7) \AA, \quad b=13.6745(7) \AA, c=20.0940(10) \AA$, $\alpha=103.554(3)^{\circ}, \beta=103.458(3)^{\circ}, \gamma=104.558(3)^{\circ}, V=3112.6(3) \AA^{3}$, $T=100(2) \mathrm{K}$, space group $P-1, Z=2,77862$ reflections measured, 12235 independent reflections $\left(R_{i n t}=0.0656\right)$. The final $R_{1}$ values were $0.0425(I>2 \sigma(I))$ and 0.0668 (all data). The final $w R\left(F^{2}\right)$ values were $0.0906(I>2 \sigma(I))$ and 0.1034 (all data). The goodness of fit on $F^{2}$ was 1.026 .

Crystal data for 12: $\mathrm{C}_{56} \mathrm{H}_{56} \mathrm{~N}_{2} \mathrm{O}_{2} \mathrm{PRhS}_{2}, \quad M=987.02$, $a=10.9365(10) \AA, b=11.6313(11) \AA, c=19.2589(17) \AA$, $\alpha=78.182(3)^{\circ}, \beta=87.291(3)^{\circ}, \gamma=81.362(3)^{\circ}, V=2370.4(4) \AA^{3}$, $T=100(2) \mathrm{K}$, space group $P-1, Z=2,55675$ reflections measured, 10320 independent reflections $\left(R_{\text {int }}=0.0230\right)$. The final $R_{1}$ values were $0.0274(I>2 \sigma(I))$ and 0.0329 (all data). The final $w R\left(F^{2}\right)$ values were $0.0662(I>2 \sigma(I))$ and 0.0712 (all data). The goodness of fit on $F^{2}$ was 1.070 .

General photophysical measurements: UV-visible absorption spectra were obtained on an Agilent 1100 Series Diode Array spectrophotometer using standard $1 \mathrm{~cm}$ path length quartz cells. Emission spectra were recorded on an Edinburgh Instruments FLSP920 spectrometer, equipped with a $450 \mathrm{~W}$ Xenon arc lamp, double monochromators for the excitation and emission pathways, and a red-sensitive photomultiplier tube (R928-P PMT) as the detector. All spectra were fully corrected for the spectral response of the instrument. Unless otherwise mentioned, the longestwavelength absorption maximum of the compound in the respective solvent was chosen as the excitation wavelength for the solution-state emission spectra. The emission spectra are independent of the excitation wavelength, and the absorption and excitation spectra are comparable across the measured range. All solutions used in photophysical measurements had a concentration lower than $10^{-6} \mathrm{M}$ to minimize inner filter effects during photoluminescence measurements. The emission quantum yields were measured using a calibrated integrating sphere from Edinburgh Instruments combined with the FLSP920 spectrometer described above. The emission was collected at right angles to the excitation source with the emission wave-length selected using a double grated monochromator and detected by a R928-P PMT.

\section{Acknowledgements}

We thank the DFG (MA 4471/4-1) and the Julius-MaximiliansUniversität Würzburg for support. A.L. thanks the DFG for a postdoctoral fellowship.

\section{References}

[1] (a) P.G. Bomben, K.C.D. Robson, B.D. Koivisto, C.P. Berlinguette, Coord. Chem. Rev. 256 (2012) 1438-1450;

(b) R.H. Crabtree, Organometallics 30 (2011) 17-19:

(c) P.-T. Chou, Y. Chi, M.-W. Chung, C.-C. Lin, Coord. Chem. Rev. 255 (2011) 2653-2665;

(d) W.-Y. Wong, C.-L. Ho, Acc. Chem. Res. 43 (2010) 1246-1256;

(e) A.F. Rausch, H.H.H. Homeier, H. Yersin, Top. Organomet. Chem. 29 (2010) 193-235;

(f) A.J. Morris, G.J. Meyer, E. Fujita, Acc. Chem. Res. 42 (2009) 1983-1994;

(g) M. Grätzel, Acc. Chem. Res. 42 (2009) 1788-1798;

(h) A.S. Polo, M.K. Itokazu, N.Y. Murakami Iha, Coord. Chem. Rev. 248 (2004) 
1343-1361;

(i) M. Grätzel, J. Photochem. Photobiol. C 4 (2003) 145-153;

(j) A. Hagfeldt, M. Grätzel, Acc. Chem. Res. 33 (2000) 269-277;

(k) K. Kalyanasundaram, M. Grätzel, Coord. Chem. Rev. 177 (1998) 347-414.

[2] S. Campagna, F. Puntoriero, F. Nastasi, G. Bergamini, V. Balzani, V. Top, Curr Chem. 281 (2007) 143.

[3] (a) E. Holder, B.M.W. Langeveld, U.S. Schubert, Adv. Mater 17 (2005) 1109-1121;

(b) H. Yersin, Top. Curr. Chem. 241 (2004) 1-26;

(c) M. Chergui, Dalton Trans. 41 (2012) 13022-13029.

[4] A. Cannizzo, A.M. Blanco-Rodriguez, A. El Nahhas, J. Ŝebera, S. Záliŝ, A. Vlçek Jr, M. Chergui, J. Am. Chem. Soc. 130 (2008) 8967-8974.

[5] (a) W. Gawelda, A. Cannizzo, V.-T. Pham, F. van Mourik, C. Bressler, M. Chergui, J. Am. Chem. Soc. 129 (2007) 8199-8206;

(b) A. Cannizzo, F. van Mourik, W. Gawelda, G. Zgrablic, C. Bressler, M. Chergui, Angew. Chem. 118 (2006) 3246-3248. Angew. Chem. Int. Ed. 45(2006) 3174-3176;

(c) J.E. Monat, J.K. McCusker, J. Am. Chem. Soc. 122 (2000) 4092-4097.

[6] P. Lind, A. Eriksson, C. Lopes, B. Eliasson, J. Phys. Org. Chem. 18 (2005) 426-433.

[7] M. Montalti, A. Credi, L. Prodi, M.T. Gandolfi, Handbook of Photochemistry, third ed., CRC Press, Boca Raton, FL, 2006.

[8] G.J. Hedley, A. Ruseckas, I.D.W. Samuel, J. Phys. Chem. A 113 (2009) 2.

[9] (a) K.R. Lee, M.-S. Eum, C.S. Chin, S.C. Lee, I.J. Kim, Y.S. Kim, Y. Kim, S.-J. Kim, N.H. Hur, Dalton Trans. (2009) 3650-3652;

(b) R.A. Kirgan, B.P. Sullivan, D.P. Rillma, Top. Curr. Chem. 281 (2007) 45-100;

(c) Y. Koga, K. Ueno, K. Matsubara, J. Polym. Sci. Part A 44 (2006) 4204-4213;

(d) S.R. Stoyanov, J.M. Villegas, D.P. Rillema, Inorg. Chem. 42 (2003) 7852-7860;

(e) J. DePriest, G.Y. Zheng, N. Goswami, D.M. Eichhorn, C. Woods, D.P. Rillema, Inorg. Chem. 39 (2000) 1955-1963;

(f) G.Y. Zheng, D.P. Rilema, J.H. Reibenspies, Inorg. Chem. 38 (1999) 794-797; (g) G.Y. Zheng, D.P. Rilema, J. DePriest, C. Woods, Inorg. Chem. 37 (1998) 3588-3592;

(h) G.Y. Zheng, D.P. Rillema, Inorg. Chem. 37 (1998) 1392-1397;

(i) Y.H. Chen, J.W. Merkert, Z. Murtaza, C. Woods, D.P. Rillema, Inorg. Chim. Acta 240 (1995) 41-47;

(j) M. Maestri, D. Sandrini, V. Balzani, A. von Zelewsky, C. Cornioley-Deuschel, P. Jolliet, Helv. Chim. Acta 71 (1988) 1053-1059;

k) C. Cornioley-Deuschel, A. von Zelewsky, Inorg. Chem. 26 (1987) 3354-3358.

[10] A. Steffen, R.M. Ward, W.D. Jones, T.B. Marder, Coord. Chem. Rev. 254 (2010) 1950-1976.

[11] (a) D.P. Rillema, A.J. Cruz, C. Moore, K. Siam, A. Jehan, D. Base, T. Nguyen, W. Huang, Inorg. Chem. 52 (2013) 596-607;

(b) Y. Chen, C. Woods, M.W. Perkovic, D.P. Rillema, J. Chem. Crystallogr. 26 (1996) 527-531;

(c) C.B. Blanton, Z. Murtaza, R.J. Shaver, D.P. Rillema, Inorg. Chem. 31 (1992) 3230-3235;

(d) B. David, U. Monkowius, J. Rust, C.W. Lehmann, L. Hyzak, F. Mohr, Dalton Trans. 43 (2014) 11059-11066;

(e) J.A. Garg, O. Blacque, T. Fox, K. Venkatesan, Inorg. Chem. 49 (2010) 11463-11472.

[12] a) H. Braunschweig, C.-W. Chiu, K. Radacki, P. Brenner, Chem. Commun. 46 (2010) 916-918;

(b) A. Wakamiya, K. Mishima, K. Ekawa, S. Yamaguchi, Chem. Commun. (2008) 579-581;

(c) C.-W. So, D. Watanabe, A. Wakamiya, S. Yamaguchi, Organometallics 27 (2008) 3496-3501;

(d) V.D.B. Bonifciocio, J. Morgado, U. Scherf, J. Polym. Sci. Part A 46 (2008) 2878-2883;

(e) K.S. Thanthiriwatte, S.R. Gwaltney, J. Phys. Chem. A 110 (2006) 2434-2439;

(f) S. Kim, K.H. Song, S.O. Kang, J. Ko, Chem. Commun. (2004) 68-69;

(g) S. Yamaguchi, T. Shirasaka, S. Akiyama, K. Tamao, J. Am. Chem. Soc. 124 (2002) 8816-8817.

[13] (a) A.J. Boydston, Y. Yin, B.L. Pagenkopf, J. Am, Chem. Soc. 126 (2004) 3724-3725;

(b) M. Hissler, P.W. Dyer, R. Reau, Coord. Chem. Rev. 244 (2003) 1-44;

(c) S. Yamaguchi, K. Tamao, J. Organomet. Chem. 653 (2002) 223-228.

[14] (a) S.H. Eichhorn, A.J. Paraskos, K. Kishikawa, T.M. Swager, J. Am. Chem. Soc. 124 (2002) 12742-12751;

(b) G. Heppke, D. Moro, Science 279 (1998) 1872-1873;

(c) H.F. Hsu, C.H. Kuo, C.F. Chen, Y.H. Lin, L.Y. Huang, C.H. Chen, K.C. Cheng,

H.H. Chen, Chem. Mater 16 (2004) 2379-2385;

(d) T.S. Jung, J.H. Kim, E.K. Jang, D.H. Kim, Y.B. Shim, B. Park, S.C. Shin,

J. Organomet. Chem. 599 (2000) 232-237; (e) K. Kishikawa, M.C. Harris, T.M. Swager, Chem. Mater 11 (1999) 867-871; (f) R. Vestberg, C. Nilsson, C. Lopes, P. Lind, B. Eliasson, E. Malmstrçm, J. Polym. Sci. Part A 43 (2005) 1177-1187;

(g) J.S. Siddle, R.M. Ward, J.C. Collings, S.R. Rutter, L. Porrés, L. Applegarth, A. Beeby, A.S. Batsanov, A.L. Thompson, J.A.K. Howard, A. Boucekkine, K. Coustas, J.-F. Halet, T.B. Marder, New J. Chem. 31 (2007) 841-851.

[15] (a) Y. Matano, H. Imahoria, Org. Biomol. Chem. 7 (2009) 1258-1271:

(b) J. Crassous, R. Reau, Dalton Trans. (2008) 6865-6876;

(c) M.G. Hobbs, T. Baumgartner, Eur. J. Inorg. Chem. (2007) 3611-3628;

(d) L.D. Quin, Curr. Org. Chem. 10 (2006) 43-78;

(e) M. Hissler, P.W. Dyer, R. Reau, Top. Curr. Chem. 250 (2005) 127-163;

(f) A.P. Sadimenko, Adv. Heterocycl. Chem. 79 (2001) 115-197;

(g) F. Mathey, Chem. Rev. 88 (1988) 429-453;

(h) A.N. Hughes, D. Kleemola, J. Heterocycl. Chem. 13 (1976) 1-12;

(i) A.N. Hughes, C. Srivanav, J. Heterocycl. Chem. 7 (1970) 1-24.

[16] (a) J.P. Rourke, A.S. Batsanov, J.A.K. Howard, T.B. Marder, Chem. Commun. (2001) 2626-2627;

(b) A.F. Hill, A.D. Rae, M. Schultz, A.C. Willis, Organometallics 26 (2007) 1325-1338;

(c) J.M. Burke, R.B. Coapes, A.E. Goeta, J.A.K. Howard, T.B. Marder, E.G. Robins, S.A. Westcott, J. Organomet. Chem. 649 (2002) 199-203.

[17] (a) V.V. Burlakov, A. Ohff, C. Lefeber, A. Tillack, W. Baumann, R. Kempe, U. Rosenthal, Chem. Ber. 128 (1995) 967-971;

(b) M. Horacek, I. Cisarova, J. Kubista, A. Spannenberg, K. Dallmann, U. Rosenthal, K. Mach, J. Organomet. Chem. 689 (2004) 4592-4600;

(c) U. Rosenthal, P.M. Pellny, F.G. Kirchbauer, V.V. Burlakov, Acc. Chem. Res. 33 (2000) 119-129.

[18] M.I. Bruce, N.N. Zaitseva, B.W. Skelton, A.H. White, Inorg. Chim. Acta 250 (1996) 129-138

[19] A. Steffen, R.M. Ward, M.G. Tay, R.M. Edkins, F. Seeler, M. van Leeuwen, L.O. Pålsson, A. Beeby, A.S. Batsanov, J.A.K. Howard, T.B. Marder, Chem. Eur. J. 20 (2014) 3652-3666.

[20] A. Steffen, M.G. Tay, A.S. Batsanov, J.A.K. Howard, A. Beeby, K.Q. Vuong, X.Z. Sun, M.W. George, T.B. Marder, Angew. Chem. Int. Ed. 49 (2010) 2349-2353. Angew. Chem. 122(2010) 2399-2403.

[21] A. Steffen, K. Costuas, A. Boucekkine, M.-H. Thibault, A. Beeby, A.S. Batsanov, A. Charaf-Eddin, D. Jacquemin, J.F. Halet, T.B. Marder, Inorg. Chem. 53 (2014) 7055-7069.

[22] M.-H. Thibault, M.G. Tay, A.S. Batsanov, J.A.K. Howard, T.B. Marder, J. Organomet. Chem. 730 (2013) 104-107.

[23] C. Sieck, M.G. Tay, M.-H. Thibault, R.M. Edkins, K. Costuas, J.-F. Halet, A.S. Batsanov, M. Haehnel, K. Edkins, A. Lorbach, A. Steffen, T.B. Marder, Chem. Eur. J. 22 (2016) 10523.

[24] (a) G. Cheng, K.T. Chan, W.P. To, C.-M. Che, Adv. Mater 26 (2014) 2540-2546; (b) W.P. To, Y.G. Liu, T.C. Lau, C.-M. Che, Chem. Eur. J. 19 (2013) 5654-5664; (c) W.P. To, K.T. Chan, G.S.M. Tong, C.S. Ma, W.M. Kwok, X.G. Guan, K.H. Low, C.-M. Che, Angew. Chem. Int. Ed. 52 (2013) 6648-6652. Angew. Chem. 125(2013) 6780-6784.

[25] F.H. Allen, O. Kennard, D.G. Watson, L. Brammer, A.G. Orpen, R. Taylor, J. Chem. Soc. Perkin Trans. 2 (1987) S1-S19.

[26] C.A. Tolman, Chem. Rev. 77 (1977) 313-348.

[27] (a) V. Lavallo, Y. Canac, A. De Hope, B. Donnadieu, G. Bertrand, Angew. Chem. Int. Ed. 44 (2005) 7236-7239. Angew. Chem. 117(2005) 7402-7405;

(b) E. Peris, R.H. Crabtree, Coord. Chem. Rev. 248 (2004) 2239-2246;

(c) C.M. Crudden, D.P. Allen, Coord. Chem. Rev. 248 (2004) 2247-2273;

(d) N.M. Scott, S.P. Nolan, Eur. J. Inorg. Chem. (2005) 1815-1828;

(e) V. César, S. Bellemin-Laponnanz, L.H. Gade, Chem. Soc. Rev. 33 (2004) 619-636;

(f) D. Ender, T. Balensiefer, Acc. Chem. Res. 37 (2004) 534-541.

[28] T.G. Appleton, H.C. Clark, L.E. Manzer, Coord. Chem. Rev. 10 (1973) 335-422.

[29] V. César, S. Bellemin-Laponnaz, L.H. Gade, Eur. J. Inorg. Chem. 17 (2004) 3436-3444.

[30] D. Tapu, D.A. Dixon, C. Roe, Chem. Rev. 109 (2009) 3385-3407.

[31] K. Powers, C. Hering-Junghans, R. McDonald, M.J. Ferguson, E. Rivard, Polyhedron 108 (2016) 8-14.

[32] L. Palacios, A. Di Giuseppe, R. Casterlenas, F.J. Lahoz, J. Pérez-Torrente, L.A. Oro, Dalton Trans. 44 (2015) 5777-5789.

[33] G.A. Grasa, Z. Moore, K.L. Martin, E.D. Stevens, S.P. Nolan, V. Paquet, H. Lebel, J. Organomet. Chem. 658 (2002) 126-131.

[34] B.J. Coe, S.J. Glenwright, Coord. Chem. Rev. 203 (2000) 5-80.

[35] C. Dai, E.G. Robins, A.J. Scott, W. Clegg, D.S. Yufit, J.A.K. Howard, T.B. Marder, Chem. Commun. 18 (1998) 1983-1984.

[36] T. Dröge, F. Glorius, Angew. Chem. Int. Ed. 49 (2010) 6940-6952. Angew. Chem. 122(2010) 7094-7107.

[37] L.J. Bourhis, O.V. Dolomanov, R.J. Gildea, J.A.K. Howard, H. Puschmann, Acta Crystallogr. Sect. A 71 (2015) 59-75.

[38] M. Sheldrick, Acta Crystallogr. Sect. A 64 (2008) 112-122. 